\title{
Article
}

\section{Tourism and Religion: Issue and implications [Book Review]}

Sharpley, Richard Anthony john

Available at http://clok.uclan.ac.uk/22134/

Sharpley, Richard Anthony john ORCID: 0000-0002-2135-3206 (2018) Tourism and Religion: Issue and implications [Book Review]. Journal of Heritage Tourism, 13 (6). pp. 556-567. ISSN 1743-873X

It is advisable to refer to the publisher's version if you intend to cite from the work. http://dx.doi.org/10.1080/1743873X.2018.1462576

For more information about UCLan's research in this area go to http://www.uclan.ac.uk/researchgroups/ and search for < name of research Group>.

For information about Research generally at UCLan please go to http://www.uclan.ac.uk/research/

All outputs in CLoK are protected by Intellectual Property Rights law, including Copyright law. Copyright, IPR and Moral Rights for the works on this site are retained by the individual authors and/or other copyright owners. Terms and conditions for use of this material are defined in the policies page.

\section{CLoK}

Central Lancashire online Knowledge www.clok.uclan.ac.uk

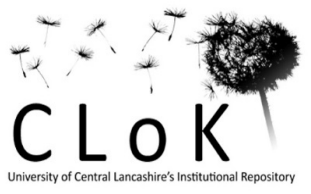


Tourism and Religion: Issue and Implications. Richard Butler and Wantanee Suntikul (Eds). Channel View Publications, Bristol, UK (2018), x11+301 pp., Hardback £199.95, ISBN 978-1-84541-645-4; Paperback £39.95, ISBN 978-1-84541-644-7; Ebook £30.00, ISBN 978$1-84541-647-8$

Tourism and religion are intimately interconnected. Travel for religious purposes, one the earliest forms of tourism, has evolved into an increasingly significant contemporary tourism market sector whilst, more generally, not only are religious places and events becoming increasingly popular amongst religious and secular visitors alike (hence the attention now paid to the economic development opportunities afforded by such travel), but also the relationship between tourism and religion is becoming both broader and more complex. It is not surprising, therefore, that increasing academic attention has been paid to tourism and religion over the last three decades.

This edited collection, then, represents an additional contribution to a burgeoning literature on the subject. Setting out to explore what is described as the increasingly 'problematic' (p.1) interaction between tourism and religion, it offers seventeen chapters structured into three sections, 'Faiths and Tourism', 'Issues and Problems' and 'Secular Tourism in Sacred Places', sandwiched between surprisingly brief and rather curious introductory and concluding chapters written by the editors. More specifically, readers of this book might have expected a more comprehensive, critical review of the extant literature in the introduction to both frame and justify the subsequent content of the book, whilst the concluding chapter, rather than drawing together the key themes emerging from the preceding chapters, engages primarily in well-rehearsed debates surrounding the spiritual dimension of contemporary tourism.

However, the main chapters are, to a greater or lesser extent, more satisfying. Commencing with a brief scene-setting chapter which unusually but effectively reproduces a speech on the touristic use of traditionally spiritual places, specifically Uluru which, interestingly, has since been declared to be off-limits to tourists by 2020, the first (and longest) section comprises a further six chapters which, for the most part, provide both historical and contemporary descriptive overviews of the relationship between tourism and particular faiths. The origins of hospitality in early Christian travel (Chapter 3 ), trends in travel in Judaism (Chapter 5) and the relationship between Shintoism and travel in Japan (Chapter 6) are clearly and concisely revealed, the relationship between tourism and, respectively, Islam and Hinduism (Chapters 4 and 7) rather less so. The section concludes with a fascinating account of research into the responses of Buddhist monks to different types of visitors to a sacred site in China in one of the book's more intriguing chapters. 
The second section ('Issues and Problems') is, perhaps, misleadingly titled, comprising as it does, first, a conceptual perspective on the religious-spiritual tourist experience followed by a further four chapters considering the development of religious tourism in difficult political environments. This is not to say that the chapters in this section are not individually effective and interesting; in 'The Vow and Tourist Travel', understandings of the religious tourist experience are enhanced by a focus on embodiment and performance whilst the case studies in Chapters 10 to 13 of conflicts between religious tourism and politics in Israel, Palestine, Myanmnar and Russia respectively offer original and critical insights. Nevertheless, it is difficult to identify any thematic issues that collectively emerge from these case studies.

The final section of the book is potentially the most interesting, the chapters mostly addressing the challenges surrounding the sharing of sacred places amongst both religious and secular tourists. Following a rather disjointed literature review and overview (but no outcomes) of a project to promote spiritual tourism amongst young people in Europe (Chapter 14), the next three chapters (15 to 17) consider the increasing touristic use of sacred places, respectively, religious and pilgrimage routes and trails, English cathedrals and Salt Lake City, the latter chapter in particular providing fascinating historical and contemporary insights into Mormonism. Chapter 18 then focuses specifically on the religious needs of tourists belonging to the three monotheistic faiths of Judaism, Christianity and Islam. Although informative, however, not only does this descriptive chapter sit uneasily in this section but it also contributes to somewhat eclectic feel of the book as a whole (a not uncommon limitation of edited collections).

More specifically, although the purpose of the book is, as previously noted, to consider issues and challenges arising from the interaction of tourism, it does so in a rather unstructured manner and, as a consequence and disappointingly, few if any over-arching themes emerge or are discussed. For example, the commercial exploitation of religious tourism and tourists and the consequential implications for the (religious) tourist experience is a contemporary challenge recognized by many and is implicit in a number of chapters, but is not addressed here. Equally, relatively few of the mostly fascinating case studies offer wider insights into the tourism-religion nexus. Nevertheless, overall this book does broaden knowledge and understanding of the interaction between tourism and religion (or more specifically, some religions) and, therefore, not only deserves a place on the library shelf but is well worth dipping in to.

Richard Sharpley

University of Central Lancashire

rajsharpley@uclan.ac.uk 